\title{
Editorial
}

\section{Indigeneity, human rights and the environment}

It is indisputable that the global environmental crisis disproportionally affects individuals and communities that are least able to withstand or adapt to the impacts of environmental destruction. Indigenous Peoples are among those most deeply affected.

The history of colonialism is a history of the dispossession of Indigenous Peoples of the lands that they and their ancestors had inhabited and cared for, and of the imposition on them of destructive 'development' policies. It is estimated that there are between 250 and 375 million Indigenous people worldwide, many of whom are now living in remote areas where they are able to continue the traditions of their ancestors and live in harmony with nature. But the 'development' agenda continues unabated, threatening Indigenous ways of life. The exhaustion of natural resources in more easily accessible areas combined with pressures on governments to grow their economies, develop infrastructure and provide employment opportunities for their people has led to increased logging, mining and other extractive activities and the building of roads and pipelines on the ancestral lands of Indigenous Peoples, often with devastating environmental consequences. ${ }^{1}$

Environmental harm is especially detrimental to Indigenous communities because, as John Knox, Special Rapporteur on Human Rights and the Environment emphasizes in his report on Biodiversity and Human Rights, Indigenous Peoples often entirely depend on the forests, plants, lakes, rivers and animals found on their traditional territories for food, shelter, fuel, medicines and other necessities of life. ${ }^{2}$ Without alternative sources of subsistence or income, detrimental environmental impacts resulting from industrial development have the potential to entirely destroy Indigenous lives and livelihoods.

The relationship of Indigenous Peoples with their ancestral territories, moreover, goes far beyond economic dependence. As the Inter-American Court of Human Rights recognizes, the relationship of Indigenous Peoples with their ancestral lands is fundamental to their entire way of being:

The culture of the members of the indigenous communities directly relates to a specific way of being, seeing, and acting in the world, developed on the basis of their close relationship with their traditional territories and the resources therein, not only because they are their

1. Human Rights Council, Report of the Special Rapporteur on the Rights of Indigenous Peoples, James Anaya: Extractive industries operating within or near indigenous territories A/HRC/18/35, paras 30-35; Inter-American Commission on Human Rights, Indigenous Peoples, Afro-Descendant Communities and Natural Resources: Protection in the Context of Extraction, Exploitation and Development Activities OEA/Ser L/V/II, Doc 47/15, 31 December 2015 paras 16-18.

2. Human Rights Council, Report of the Special Rapporteur on the issue of human rights obligations relating to the enjoyment of a safe, clean healthy and sustainable environment, John Knox (Biodiversity and Human Rights) A/HRC/34/49, 19 January 2017 para 22. 
main means of subsistence, but also because they are part of their worldview, their religiosity, and therefore, of their cultural identity. ${ }^{3}$

The vulnerability of Indigenous Peoples to the detrimental impact of environmental harm is further exacerbated by poverty and marginalization. Poor and marginalized communities often lack political representation and are ignored in the planning and approval processes for mining and other industrial development, perpetuating the cycle of environmental ruin, destruction of livelihoods, devastation of communities and poverty.

Indigenous Peoples have responded to the global environmental crisis by coming together to challenge the dominant 'development' agenda and to offer an alternative vision for 'living well'. 4 The 1992 Kari-Oca Declaration, which emerged from a gathering of Indigenous Peoples in Kari-Oca, Brazil, preceding the United Nations Conference on Environment and Development in Rio de Janeiro (Rio Earth Summit), sets out a common vision of the interdependence of humans and the environment and emphasizes the primordial responsibility of Indigenous Peoples to care for their lands in order to pass them on to future generations. ${ }^{5}$ The Kari-Oca conference was an important milestone not only in articulating an Indigenous vision of the co-dependence of humans and nature and the concomitant responsibility to protect the environment, but also in mobilizing an international movement for Indigenous Peoples' rights. Twenty years later, Kari-Oca II, took place in advance of the UN Conference on Sustainable Development (Rio+20). The Kari-Oca II Declaration rejects the commodification of nature in specific terms and reaffirms the 'inseparable relationship between humans and the Earth, inherent to Indigenous Peoples':

Mother Earth is the source of life which needs to be protected, not a resource to be exploited and commodified as 'natural capital.' We have our place and responsibilities within Creation's sacred order. We feel the sustaining joy as things occur in harmony with the Earth and with all life that it creates and sustains. We feel the pain of disharmony when we witness the dishonour of the natural order of Creation and the continued economic colonization and degradation of Mother Earth and all life upon her. ${ }^{6}$

Other declarations issued by Indigenous Peoples over the past decades restate the themes of Kari-Oca I and II, and provide a distinct, alternative approach based on the knowledge, values and practices of Indigenous Peoples, to address the environmental crisis. The 2010 People's Agreement of Cochabamba, issued by the World People's

3. Inter-American Court of Human Rights, Case of the Yakye Axa Indigenous Community $v$ Paraguay (Merits, Reparations and Costs) Series C No 125 (17 June 2005) para 135; see also Inter-American Commission on Human Rights, Indigenous and Tribal Peoples' Rights over their Ancestral Lands and Natural Resources: Norms and Jurisprudence of the Inter-American Human Rights System OEA/Ser.L/V/II. Doc 56/09 (30 December 2009) paras 55-7.

4. See for example, Rio+20 International Conference of Indigenous Peoples on SelfDetermination and Sustainable Development, Indigenous Peoples International Declaration on Self-Determination and Sustainable Development, Rio de Janeiro, 19 June $2012<\mathrm{http} / / /$ www.forestpeoples.org/en/topics/sustainable-livelihoods/publication/2012/indigenous-peoplesrelease-rio-20-declaration>.

5. World Conference of Indigenous Peoples on Territory, Environment and Development, Kari-Oca Indigenous People's Declaration, Kari-Oca, Rio de Janeiro, Brazil 1992.

6. Indigenous Peoples Global Conference on Rio+20 and Mother Earth, Kari-Oca 2 Declaration Kari-Oca, Rio de Janeiro, Brazil 2012. 
Conference on Climate Change and the Rights of Mother Earth, held in Cochabamba, Bolivia, expresses this as follows:

It is imperative that we forge a new system that restores harmony with nature and among human beings. And in order for there to be balance with nature, there must first be equity among human beings. We propose to the peoples of the world the recovery, revalorization, and strengthening of the knowledge, wisdom and ancestral practices of Indigenous Peoples, which are affirmed in the thought and practices of 'Living Well,' recognizing Mother Earth as a living being with which we have an indivisible, interdependent, complementary and spiritual relationship. ${ }^{7}$

Notwithstanding the vulnerability of Indigenous Peoples, international human rights law makes very little explicit provision for their rights. The International Labour Organization (ILO) Convention No 169 is the only legally binding international treaty recognizing the rights of Indigenous Peoples, providing for the protection of a wide range of rights including rights to land, natural resources and a healthy environment; equality; rights to participation and consultation in decision-making; and rights to recognition of culture and religion. States are obliged under the Convention to adopt 'special measures' to safeguard Indigenous Peoples, their culture and environment. ${ }^{8}$ Within the UN system, standardsetting in relation to the treatment of Indigenous Peoples has been mainly followed through soft law, developed via the special procedures and other mechanisms of the UN Commission on Human Rights and its successor, the UN Human Rights Council, and culminating in the adoption of the landmark 2007 UN Declaration on the Rights of Indigenous Peoples (UNDRIP). ${ }^{9}$ A spectrum of rights are covered by UNDRIP, including the rights to self-determination and equality; to live as distinct peoples; to the maintenance of Indigenous cultures, identities, customs, religions and languages; to land; to participation in decision-making; and to protection of the environment. In spite of criticisms that the international human rights framework is rooted in the Western 'law of nations' tradition that has been used to justify colonialism and is incompatible with many aspects of Indigenous customary law and tradition, Indigenous rights have become a powerful tool in the struggle for recognition of state obligations to protect the rights of Indigenous Peoples. Such rights have had positive impacts, for example, in ending practices such as forced assimilation and the dispossession of land. ${ }^{10}$ An array of international human rights and environmental instruments recognize the rights to cultural heritage of Indigenous Peoples, in particular including rights to traditional knowledge. While some critics question the adequacy of such protection, others argue that there is much more scope to use international environmental and human rights law to protect the culture and traditional knowledge of Indigenous Peoples than has been explored to date. ${ }^{11}$ More recently, the Paris Agreement became the

7. World People's Conference on Climate Change and the Rights of Mother Earth, People's Agreement of Cochabamba, Cochabamba, Bolivia 22 April $2010<\mathrm{https}$ ///therightsofnature.org/ cochabama-rights/>.

8. ILO Convention 169 concerning Indigenous and Tribal Peoples in Independent Countries (adopted 27 June 1989, entered into force 5 September 1991) 1650 UNTS 383.

9. UN General Assembly Resolution 61/295, Declaration on the rights of Indigenous Peoples (13 September 2007).

10. See B Saul, Indigenous Peoples and Human Rights (Bloomsbury 2016).

11. See A Savaresi, 'Traditional Knowledge and Climate Change: A New Legal Frontier?' (2018) 9 JHRE 32. 
first climate treaty to acknowledge the importance of the role of traditional knowledge in assessing and mitigating climate change impacts. ${ }^{12}$

Despite this general context reflecting increased activism by Indigenous Peoples, more awareness of Indigenous cultures, growing legal recognition of Indigenous rights, and increased understanding of the importance of traditional knowledge in protecting the environment, one of the persistent themes running through the contributions to this edition of the Journal of Human Rights and the Environment is the continuing failure to hear Indigenous (and other minority) voices in decisions about the environment.

Irene Watson's contribution reflects on the violative impact of colonization on Aboriginal Peoples and their law in Australia. The marginalization of Indigenous Peoples, she argues, has been achieved by means of the imposition of a dominant version of international law that refused to recognize First Nations Peoples as subjects and legitimated the 'authority' of the colonial power to determine the status of Indigenous Peoples in Australia. International law also legitimated the legal concept of terra nullius that was employed to dispossess First Nations and to provide a legal justification for the European settling of their lands. The imposition of the doctrine of terra nullius and the disregard of aboriginal law, Watson argues, has 'de-centred' Aboriginal Peoples, their law, knowledge and way of life, and sanctioned development on their lands that threatens the environment, as demonstrated by a number of compelling case studies that she discusses. But, Watson powerfully asserts, First Nations, their laws and their knowledge systems continue to exist, and Aboriginal communities continue to live and maintain a way of being in the world that is different from the dominant Euro-centric way of life. She argues that 're-centring' Aboriginal knowledge and way of being is crucial if the destructive forces of development and commodification of nature are to be arrested in order to secure the future of life on earth. This involves re-establishing a relationship between humans and the environment that is based on caring for the environment and living in harmony with nature. In order to achieve this, a reframing of the dialogue between Indigenous epistemologies and western knowledge systems is needed, a reframing that must begin with engagement with First Nations laws as law based on a deep understanding of life on earth, rather than as primitive fables and songs that have no relevance to modern society. Continuing to ignore Aboriginal knowledge and law, risks a potential 'epistemicide' and 'juridicide', Watson warns. Such a dialogue requires equality, yet equality is continually negated by continued adherence to the doctrine of terra nullius and the denial of self-determination. In order for dialogue between First Nations and the non-Indigenous world to become possible, it is necessary to acknowledge the damage wrought by colonialism and ideologies that prioritize progress at any cost' and to 're-centre' an Aboriginal worldview that prioritizes real equality and 'collective care for country', rendering that worldview both visible and audible once more.

Like Watson, Louisa Parks emphasizes the importance of voice in democratic decision making and in realizing self-determination, often denied to minorities. In 'Spaces for Local Voices', Parks focuses on the Convention on Biological Diversity (CBD) and asks whether decision making under the CBD provides space for divergent views of indigenous and local communities and whether their voices are heard and have an impact on policy making. The critical literature on global environmental governance argues that decision making under the CBD is dominated and shaped by a worldview based on a capitalist conception of what has value and on a separation of nature and

12. Paris Agreement (Paris, 12 December 2015, in force 4 November 2016) UNTS number not yet available. 
culture that feeds into and limits policy choices. In spite of a growing understanding of the importance of diverse views in environmental decision making, alternative voices are often not heard. Parks uses a detailed discourse analysis in seeking to understand whether and to what extent spaces exist within CBD processes, particularly in relation to decision making by the Conferences of the Parties (COPs), for local and Indigenous voices. Her analysis reveals a more complex picture than is presented in the existing critical literature. The point of departure for her study is that meaning is constructed through interaction and that meaning therefore changes depending on context and over time. The aim of Parks' study is to understand the dynamic interpretation and implementation of the CBD via COP decisions and the extent to which space is provided for the views of Indigenous and other minority communities to be taken into account. Her findings indicate that while there is potentially space for Indigenous and other minority voices within COP discourse, this does not always translate into actual participation. Parks concludes that the value of her study is to provide evidence that the potential spaces for Indigenous and other minority voices are much more varied across discourses and across time than other studies have found. However, Parks suggests, further work is needed to both confirm how open the CBD is to alternative voices, and to contextualize her study in order to gain an understanding of exactly how discursively open global environmental governance is.

In her contribution to this edition, Miriam Cullen considers how to provide recourse, and thereby voice, to subnational minority communities, including Indigenous communities, who are displaced as a result of damage to their homes and livelihoods caused by climate change. The Torres Strait Islanders are one such group, threatened by rising sea levels and facing displacement as their homes, livelihoods and communities are 'eaten by the sea'. The consequences for islanders, who, like many other Indigenous communities, have very close links to territory, are not only loss of their land, but loss of customs, culture and community. Cullen suggests that a communication to the UN Human Rights Committee offers the possibility of redress for communities who are particularly vulnerable to the negative impacts of climate change, yet who have no voice in the formulation of national climate policy because of their minority status and isolated location. She argues that the Torres Strait Islanders are rendered even more voiceless by the difficulty in obtaining legal redress for the effects of climate change under Australian law. Cullen emphasizes that litigation brought to challenge states' failure to address climate change has met with some success recently and that climate science has become a key element in this success. She identifies a number of specific rights under the International Covenant on Civil and Political Rights (ICCPR), which, she suggests, provide a strong basis for a UN Human Rights Committee (HRC) communication, including article 27, which provides protection for the rights of minorities, including Indigenous communities, to 'enjoy their own culture'. The connection between the right to life protected under article 6 ICCPR and protection of the environment is accepted by regional human rights courts, but the HRC has not, to date, specifically recognized it. While the HRC has not endorsed a substantive right to a healthy or sustainable environment, Cullen argues that a claim by the Torres Strait Islanders would provide an ideal opportunity for the HRC to engage with this issue while providing the Islanders with an opportunity to be heard.

The final contribution, by Cordelia Bähr, Ursula Brunner, Kristin Casper and Sandra Lustig, takes up the theme of voices for vulnerable groups in the context of climate litigation. Their article documents legal action brought by KlimaSeniorinnen Schweiz (Senior women for Climate Protection Switzerland), an organization of senior women, against the Swiss government, challenging the government's failure to implement adequate 
climate policies and mitigation measures in compliance with Switzerland's international obligations to mitigate climate change. The key argument in the case is that the Swiss government's climate policies violate the rights of older women to life and health protected under both the Swiss constitution and the European Convention on Human Rights (ECHR). Like Cullen, Bähr and her colleagues emphasize the increasing success of climate change litigation and the importance of climate science in supporting such claims: The KlimaSeniorinnen claim relies on scientific evidence that older women in Switzerland are a group highly vulnerable to the detrimental effects of climate change. The article argues that there is growing evidence from litigation brought in diverse jurisdictions that courts are increasingly willing to adjudicate human rights claims in cases such as KlimaSeniorinnen based on the failure by governments to take action to meet their global environmental commitments, and that the arguments presented in this case are equally applicable to other vulnerable groups. Litigation provides an important avenue for vulnerable and marginalized groups to make their voices heard.

All the contributions in this issue highlight the growing attention given to the role of human rights in providing avenues to enhance environmental protection, and the increasing emphasis placed on the environmental responsibilities of states within international human rights law. Giving voice to Indigenous Peoples in both environmental and human rights fora provides opportunities to present visions of a future in which the obligation to protect the environment is not only clearly established in law but is also an integral part of the way of life of communities. Obliging states to hear alternative worldviews that challenge the dominant narrative of 'development' and the commodification of nature, and which demonstrate ways of life in harmony with nature, is the first step to making such a future a reality.

Evadne Grant Editor, Associate Head of Department, Bristol Law School, University of the West of England, Bristol, UK 